Govindasamy, A. V.; Briaud, Jean-Louis; Kim, D.; Olivera, F.; Delphia, J.; Gardoni, P.

\title{
Observational Method for Estimating Future Scour Depth at
} Existing Bridges

Verfügbar unter / Available at:

https://hdl.handle.net/20.500.11970/100256

Vorgeschlagene Zitierweise / Suggested citation:

Govindasamy, A. V.; Briaud, Jean-Louis; Kim, D.; Olivera, F.; Delphia, J.; Gardoni, P. (2010): Observational Method for Estimating Future Scour Depth at Existing Bridges. In: Burns, Susan E.; Bhatia, Shobha K.; Avila, Catherine M. C.; Hunt, Beatrice E. (Hg.): Proceedings 5th International Conference on Scour and Erosion (ICSE-5), November 7-10, 2010, San Francisco, USA. Reston, Va.: American Society of Civil Engineers. S. 41-65. 


\title{
Observational Method for Estimating Future Scour Depth at Existing Bridges
}

\author{
A.V. Govindasamy ${ }^{1}$, J.-L. Briaud ${ }^{2}$, D. Kim ${ }^{3}$, F. Olivera ${ }^{4}$, P. Gardoni ${ }^{5}$, and J. Delphia ${ }^{6}$ \\ ${ }^{1}$ Staff Engineer, Geocomp Corporation, 1145 Massachusetts Avenue, Boxborough, \\ MA 01719; PH (978) 621-8106; email: agovindasamy@geocomp.com \\ ${ }^{2}$ Professor and Holder of the Buchanan Chair, Zachry Dept. Of Civil Engineering, \\ Texas A\&M University, College Station, TX 77840; PH (979) 845-3795; \\ email: briaud@tamu.edu
}

${ }^{3}$ GIS Developer, Dewberry, 8401 Arlington Boulevard, Fairfax, VA 22031; PH (703) 206-0847; email: dokim@dewberry.com

${ }^{4}$ Associate Professor and Head of the Water Resources Division, Zachry Dept. Of Civil Engineering, Texas A\&M University, College Station, Texas, 77840; PH (979) 845-1404; email: folivera@civil.tamu.edu

${ }^{5}$ Associate Professor, Zachry Dept. Of Civil Engineering, Texas A\&M University, College Station, Texas, 77840; PH: (979) 845-4340; email: pgardoni@civil.tamu.edu

${ }^{6}$ Geotechnical Engineer, Texas Department of Transportation Bridge DivisionGeotechnical Branch, Austin, Texas; PH: (512) 416-2359; email: jdelphi@dot.state.tx.us

\section{ABSTRACT}

Bridge scour can cause damage to bridge foundations and abutments. Bridges with foundations that are unstable for calculated and/or observed scour conditions are termed scour critical bridges. There are approximately 17,000 scour critical bridges in the United States. This designation comes in part from the use of over-conservative methods that predict excessive scour depths in erosion resistant materials. Other methods capable of overcoming this over-conservatism are uneconomical because they require site-specific erosion testing. This paper proposes a new bridge scour assessment method. The new method, termed Bridge Scour Assessment 1 (BSA 1) is the first part of a three level bridge scour assessment procedure that was developed for the Texas Department of Transportation. It does not require site-specific erosion testing and eliminates the over-conservatism in current methods. BSA 1 uses charts that extrapolate or interpolate measured scour depths at the bridge to obtain the scour depth corresponding to a specified future flood event. The scour vulnerability depends on the comparison between the predicted and allowable scour depths. This paper also includes a new hydraulic-hydrologic analysis procedure for the determination of flow parameters required in the scour analysis. This procedure was developed for the State of Texas, and is economical and reasonably reliable from a hydrologic standpoint. This procedure is versatile as it can be applied to any region with sufficient flow gages. The 11 case histories used to validate BSA 1 showed good agreement between predicted and measured values. BSA 1 was then applied to 16 bridges where 6 out of 10 bridges classified as scour critical by current methods were found to be stable. These indicate that the method allows for more realistic evaluation of bridges for scour 
while not requiring site-specific erosion testing. BSA 1 was finalized in April 2009 and six months later has already been used by Texas Department of Transportation engineers to evaluate 350 scour critical bridges in the State of Texas.

\section{INTRODUCTION}

Bridge scour is the term describing the loss of geomaterials due to water flowing around bridge supports. Bridge foundations can be undermined if excessive scour takes place, possibly leading to the failure of the bridge. Current standard bridge scour assessment methods in use are either qualitative initial evaluations that can be unreliable or quantitative scour depth evaluations that are overly conservative when applied to erosion resistant materials.

There are approximately 17,000 scour critical bridges in the United States (Pagan-Ortiz 1998). In the State of Texas alone, there are 600 bridges designated as scour critical. This designation comes in part from the use of methods that predict excessive scour depths in erosion resistant materials. This paper presents a quantitative bridge scour assessment method, termed Bridge Scour Assessment 1 (BSA 1) which accounts for time-dependent scour depth using field measurements. This method eliminates the over-conservatism in erosion resistant materials and does not require site-specific erosion testing. BSA 1 is part of a three phase comprehensive bridge scour assessment package which includes maximum scour depth and more detailed time-dependent scour depth calculations in the remaining two phases, termed BSA 2 and BSA 3 (Govindasamy 2009 and Briaud et al. 2009).

This paper deals with local scour, more specifically pier and contraction scour. The contribution of abutment scour towards the total scour depth is not included because it is usually more practical and favorable to protect the abutment with riprap or other scour countermeasures.

\section{CURRENT PRACTICE}

Current bridge scour evaluation procedures rely upon three categories of assessment methods. The first category, termed Level 1 analysis, is a preliminary scour evaluation procedure that is based on field observations and is primarily qualitative in nature, but could also rely on simplified scour depth-hydraulic parameter relationships that are mainly based on flume tests in sand. This category does not utilize actual measured scour data. The second and third categories, termed Level 2 and Level 3 analysis, involve more detailed calculations of maximum scour depth based on flume tests in sand. The first method does not provide realistic results in many cases due to its reliance on a more qualitative form of assessment. The second and third methods are often conservative in the case of clays, which are known to erode at a much slower rate than sand.

Preliminary scour evaluation procedures have been developed by or for several state departments of transportation (DOTs). For example, the Montana DOT, in collaboration with the United States Geological Survey (USGS), developed a rapid scour evaluation process that relies upon calculated scour depth- measured hydraulic parameter relationships (Holnbeck and Parrett 1997). A similar method has also been 
adopted by the Missouri DOT (Huizinga and Rydlund 2004). The Tennessee DOT uses an initial evaluation process that utilizes a qualitative index based on field observations to describe potential scour related problems (Simon et al. 1989). Similar qualitative methods have been adopted by the California, Idaho, and Texas DOTs, and the Colorado Highway Department for their initial assessment of bridges for scour. Johnson (2005) presented a preliminary assessment procedure that individually rates 13 stream channel stability indicators, which are then summed to provide an overall score that places a bridge in one of four categories: excellent, good, fair, and poor (Govindasamy et al. 2008).

Current practice for more detailed scour evaluation is heavily influenced by two Federal Highway Administration (FHWA) hydraulic engineering circulars (HECs) called HEC-18 and HEC-20 (Richardson and Davis 2001, and Lagasse et al. 1995). These circulars have two major categories of bridge scour calculations, termed here as HEC-18 Sand and HEC-18 Clay. The HEC-18 Sand method in known to be overly conservative in the case of clays and some rocks because it is based on flume tests in sand and essentially estimates the maximum (or equilibrium) scour depth, $Z_{\max }$ that can occur at the bridge. It does not account for time-dependent scour, $Z_{\text {final }}$. The HEC-18 Clay method (Briaud et al. 1999 and Briaud et al. 2005) consists of pier and contraction scour models that are capable of accounting for time-dependent scour. HEC-18 Clay, previously referred to as the Scour Rate in Cohesive Soils (SRICOS) method requires site-specific erosion testing (Govindasamy 2008).

\section{THE HEC-18 CLAY METHOD}

The HEC-18 Clay method predicts the scour depth versus time curve around a cylindrical pier and in bridge contractions in clay. This method was employed in the development of BSA 1. The method involves obtaining soil samples at the bridge site and testing it in the Erosion Function Apparatus or EFA to obtain the erosion function (Briaud et al. 2001a). Further analysis is carried out based on the erosion function to determine the scour depth versus time curve. This curve, representing the time-dependent scour depth is modeled as a hyperbola with the initial rate of scour as the initial slope and $Z_{\max }$ as the asymptotic value of the hyperbola. The reader is referred to Briaud et al. (1999) and Briaud et al. (2005) for detailed descriptions of HEC-18 Clay.

\section{BRIDGE SCOUR ASSESSMENT 1 (BSA 1)}

The main idea behind BSA 1 is that the best information available for existing bridges including scour critical bridges is not equations and calculations but the observations at the bridge site and that these observations can be extrapolated or interpolated to predict the scour depth under a major flood in the future. More specifically, the scour depth corresponding to a specified future flood event can be obtained from scour depth observations at the site and from charts that relate the future scour depth ratio $\left(Z_{\text {fut }} / Z_{\mathrm{mo}}\right)$ to the future velocity ratio $\left(V_{\text {fut }} / \mathrm{V}_{\mathrm{mo}}\right)$. Here, $Z_{\text {fut }}$ is the scour depth corresponding to a specified future flood, $Z_{\mathrm{mo}}$ is the maximum observed scour at the bridge, $V_{\text {fut }}$ is the velocity corresponding to the specified future flood, and $V_{\text {mo }}$ is the 
maximum velocity observed at the bridge until the time $Z_{m o}$ is measured. These charts are termed the Z-Future Charts (Govindasamy 2009 and Briaud et al. 2009). The scour vulnerability of the bridge depends on the comparison between $Z_{\text {fut }}$ and the allowable scour depth of the foundation, $Z_{\text {thresh }} . V_{\text {fut }} / V_{\text {mo }}$ is obtained through a simplified hydrologic analysis that is presented later in this paper and answers the question: "what is the highest flood that this bridge has seen since its construction?" BSA 1 consists of two flowcharts, i.e. the BSA 1 (Uniform Deposit) and BSA 1 (Multilayer Analysis) flowcharts. BSA 1 (Uniform Deposit) shown in Figure 1 is for a bridge site that is underlain by a uniform deposit or for a scour depth being investigated that is not expected to exceed the top layer of a multilayer deposit. BSA 1 (Multilayer Analysis) is used for layered deposits when the scour depth being investigated penetrates beyond the top layer. BSA 1 (Multilayer Analysis) is beyond the scope of this paper. The reader is referred to Govindasamy (2009) and Briaud et al. (2009) for a detailed description of the method.

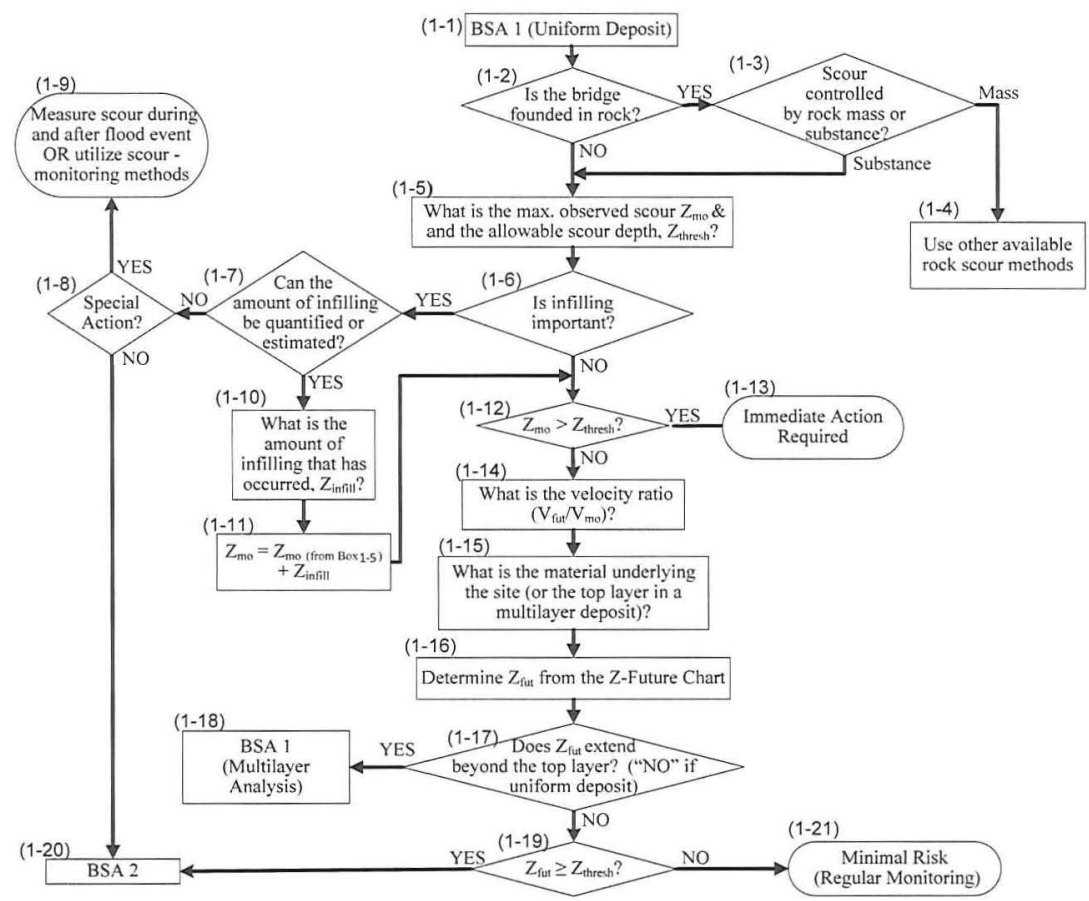

FIGURE 1 BSA 1 (Uniform Deposit) Flowchart. 


\section{The Z-Future Charts}

To develop the Z-Future Charts, HEC-18 Clay simulations were carried out by employing an equivalent time to represent the age of the bridge, varying the pier and contraction scour parameters, and the material underlying the bridge site. The concept of equivalent time was developed for pier and contraction scour by (Briaud et al. $2001 \mathrm{~b}$ and Wang 2004), who define it as the time required for the maximum velocity in the hydrograph to create the same scour depth as the one created by the complete hydrograph. This concept was needed to enable a large number of simulations to be carried out through more simple calculations rather than complex hydrograph based analysis. The materials underlying the site are in accordance with five of six erosion categories in that are presented in what is termed the Erosion Function Chart (Figure 2) (Govindasamy 2009 and Briaud 2008). These simulations computed the time-dependent scour depth as a result of two consecutive flows having velocities $V_{\text {mo }}$ and $\mathrm{V}_{\text {fut }}$, respectively.

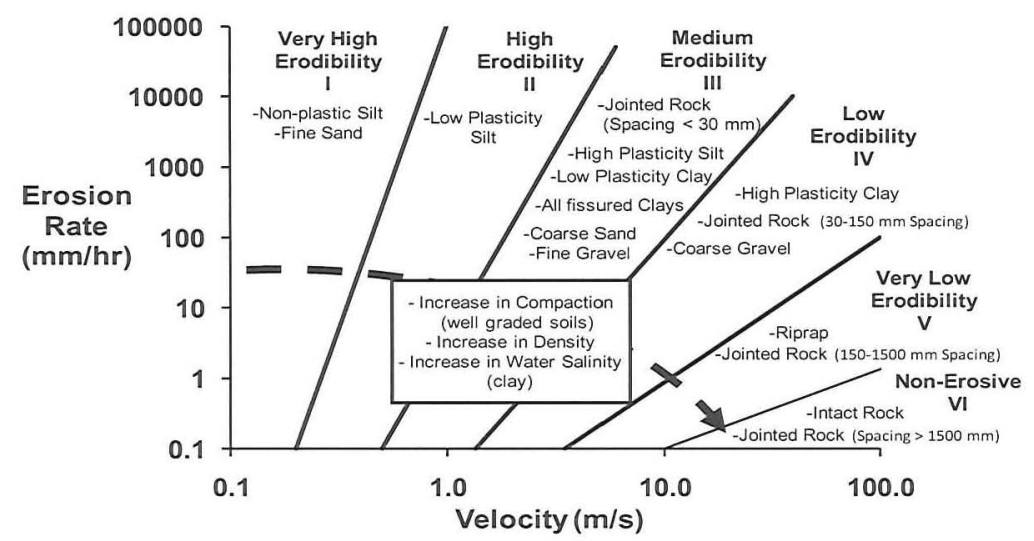

FIGURE 2 The Erosion Function Chart.

The material categories involved in these simulations are Erosion Categories I through V. Category VI was omitted from the simulations since materials that fall under this category are non-erosive.

HEC-18 simulations for pier and contraction scour employing the equivalent time concept described above were carried out by creating various combinations of the following parameters:

- $\mathrm{V}_{\text {fut }}$ and $\mathrm{V}_{\text {mo }}$ ranging from $0.3 \mathrm{ft} / \mathrm{s}(0.1 \mathrm{~m} / \mathrm{s})$ to $11.5 \mathrm{ft} / \mathrm{s}(3.5 \mathrm{~m} / \mathrm{s})$, which is well within the velocity range of flow in most rivers;

- Upstream water depth, $\mathrm{H}_{1}$, ranging from $16.4 \mathrm{ft}(5 \mathrm{~m})$ to $65.6 \mathrm{ft}(20 \mathrm{~m})$; 
- Channel contraction ratio, $\mathrm{R}_{\mathrm{c}}$, which is the ratio of the contracted channel width to the uncontracted channel width, ranging from 0.5 to 0.9 ;

- Soil-critical velocity, $\mathrm{V}_{\mathrm{c}}$, according to the five material categories investigated;

- $\quad$ Pier diameter, $\mathrm{D}$, ranging from $0.3 \mathrm{ft}(0.1) \mathrm{m}$ to $32.8 \mathrm{ft}(10.0 \mathrm{~m})$;

- Age of the bridge, thyd, ranging from 5 years to 75 years.

The simulations provided approximately 360,000 combinations of the above parameters for each material category and age of the bridge. The Z-Future Charts resulting from this is shown in Figure 3. The data points on the figure have been omitted to improve the clarity of the curves. The curves are essentially upper bound envelopes of the data points from the simulations. The reader is referred to (Govindasamy 2009 and Briaud et al. 2009) for the data points. The $Z_{\text {fut }}$ values were normalized with the corresponding $Z_{\text {mo }}$ values, and the $V_{\text {fut }}$ values were normalized with the corresponding $\mathrm{V}_{\text {mo }}$ values and subsequently plotted against each other to form the Z-Future Charts.

For the case of Category I and II materials, two ranges of pier diameter $(0.1 \mathrm{~m}$ to $1.0 \mathrm{~m}$ and $1.0 \mathrm{~m}$ to $10 \mathrm{~m}$ ) are represented by two curves in the same figure (Figure 3(a)). For the case of Category III materials, the Z-Future Charts were separated into two charts, i.e., one for $\mathrm{D}$ ranging from $0.1 \mathrm{~m}$ to $1.0 \mathrm{~m}$ and the other for $\mathrm{D}$ ranging from $1.0 \mathrm{~m}$ to $10.0 \mathrm{~m}$ (Figures $3(\mathrm{~b})$ and 3 (c)). This was done due to notable difference in $Z_{\text {fut }} / Z_{\text {mo }}$ ratios from these two ranges of pier diameters. The pier diameters for all other categories were lumped together, i.e., ranging from $0.1 \mathrm{~m}$ to $10.0 \mathrm{~m}$ since there was no significant difference due to the low erosion rates.

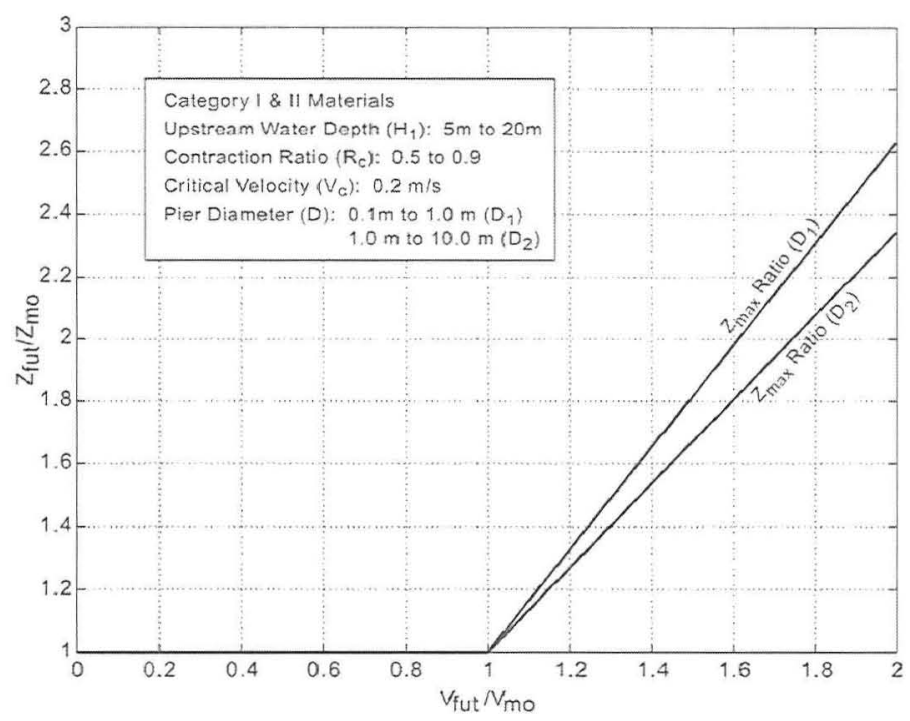

FIGURE 3(a) Z-Future Chart for Category I \& II Materials 


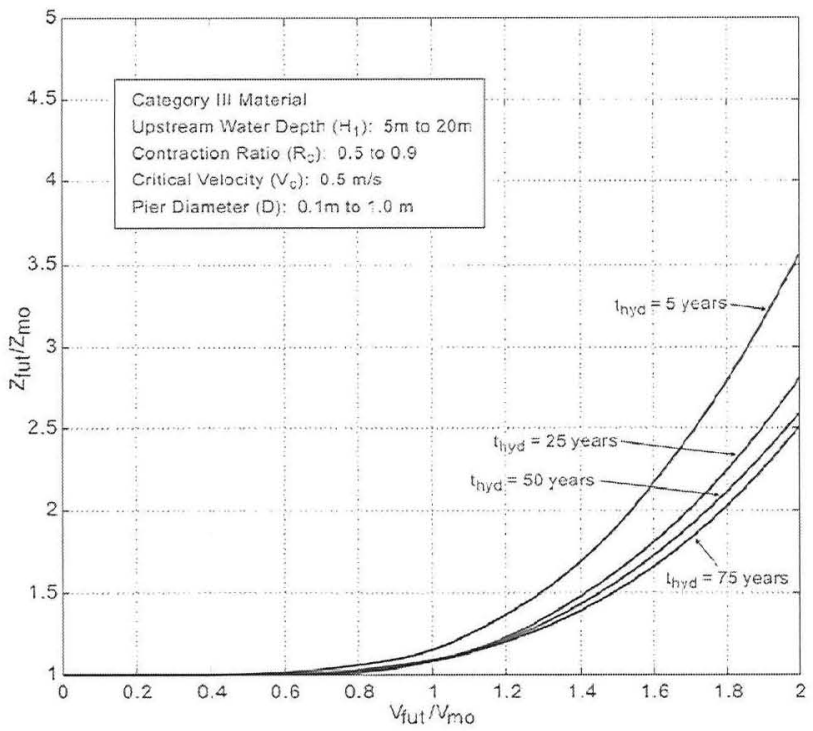

FIGURE 3(b) Z-Future Chart for Category III Materials (Pier diameter: $0.1 \mathrm{~m}$ to $1.0 \mathrm{~m})$.

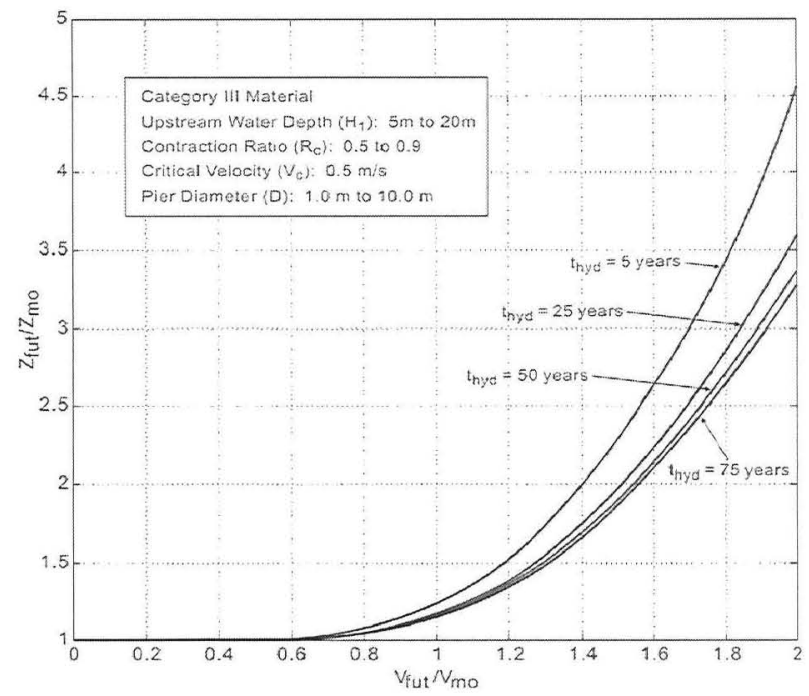

FIGURE 3(c) Z-Future Chart for Category III Materials (Pier diameter: $1 \mathrm{~m}$ to $10 \mathrm{~m})$. 


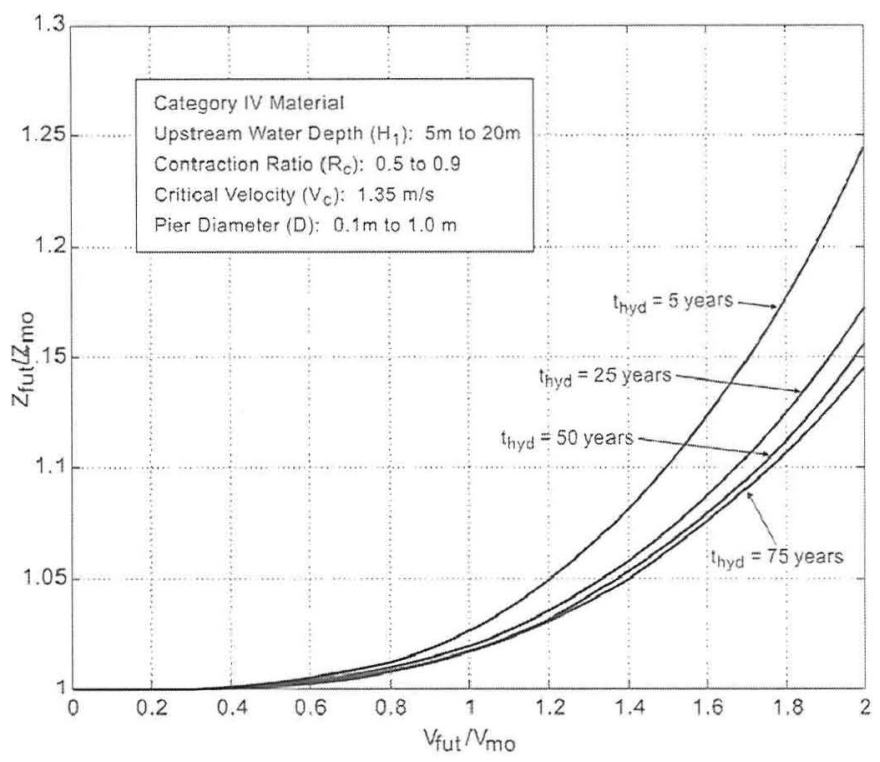

FIGURE 3(d) Z-Future Chart for Category IV Materials.

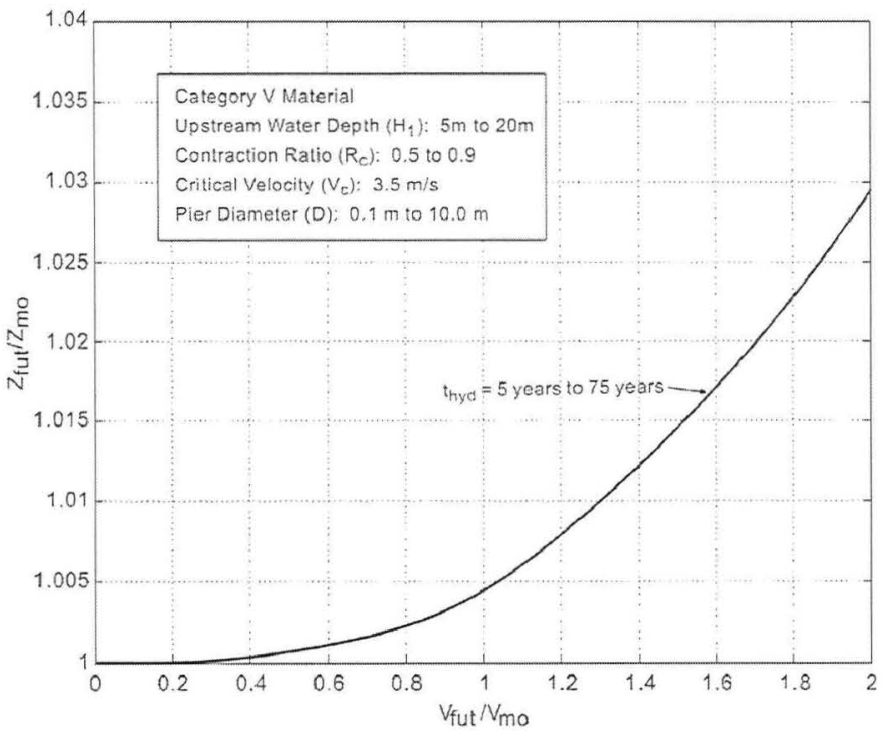

FIGURE 3(e) Z-Future Chart for Category V Materials. 
In general, the $\mathrm{Z}$-Future Charts lead to the determination of $\mathrm{Z}_{\text {fut }}$ by employing the following relationship:

$$
\mathrm{Z}_{\text {fut }}=\mathrm{Z}_{\mathrm{mo}} \times f\left(\mathrm{~V}_{\text {fut }} / \mathrm{V}_{\mathrm{mo}}\right)
$$

where $f$ is some function of $\left(\mathrm{V}_{\text {fur }} / \mathrm{V}_{\text {mo }}\right)$ obtained from the Z-Future Charts and is always equal to or greater than unity (for the case of clear-water scour, as considered in these simulations). The velocity ratio $\left(\mathrm{V}_{\text {fut }} / \mathrm{V}_{\mathrm{mo}}\right)$ is plugged into the chart by the user to obtain the value of the function $f$, based on the material type, age of the bridge, and pier scour and contraction scour parameters. $Z_{\text {mo }}$ is obtained from bridge inspection and measurement records.

\section{The BSA-1 Procedure and Flowchart}

The BSA-1 flowchart is shown in Figure 1. The first step in BSA 1 is to identify whether the bridge is founded in rock or not. If the bridge is founded in rock, BSA 1 then separates rock mass and rock substance-controlled erosion. Rock masscontrolled erosion occurs when reactions of rock materials to hydraulic stress are controlled by rock mass properties such as fracture and joint spacing, bedding planes, folding, and spatial orientation (Cato 1991). In rock mass-controlled erosion, the rock materials are eroded and transported as blocks. Rock substance-controlled erosion is the erosion process that is governed by the property of the mineral grains forming the rock. In BSA 1 (Uniform Deposit), scour assessments of rock materials that undergo rock mass-controlled erosion should use other rock scour assessment methods. Rock materials that undergo rock substance-controlled erosion are treated as soils in BSA 1.

As mentioned above, the Z-Future Charts were developed based on clearwater conditions. However, if live-bed scour has taken place, the depth of the scour hole measured during bridge inspections could be the scour depth after infilling has occurred. This would be the case if the bridge inspection is carried out either during the falling stage of the flood or after the flood event altogether. Since the Z-Future Charts are developed for clear water scour conditions, if the measurements taken during the bridge inspection do not account for possible infilling, $\mathrm{Z}_{\text {fut }}$ would be underpredicted, as implied by Equation (1). This would therefore lead to an unconservative or even erroneous assessment of the bridge for scour. Several options are available in BSA 1 when infilling is expected to occur:

1. Quantifying the amount of infilling that has occurred, $Z_{\text {infill }}$. This can be done, for example by using engineering judgement and local experience, performing sediment transport calculations, model tests, or probing into the scour hole to roughly identify the extent of the infilled material. In this case, the value of $Z_{\text {mo }}$ used in Equation (1) is the summation of the measured scour depth and $Z_{\text {infill. }}$.

2. Taking special actions such as measuring the scour depth during and after flood events or utilizing scour-monitoring methods.

3. Carrying out BSA 2 or BSA 3, which are beyond the scope of this paper.

If the site is underlain by a multilayer deposit and $Z_{\text {fut }}$ extends beyond the top layer, then BSA 1 (Multilayer Analysis) as presented in Govindasamy (2009) and Briaud et al. (2009) should be carried out. Otherwise, if the site is underlain by a 
uniform deposit or if $\mathrm{Z}_{\text {fut }}$ does not extend beyond the top layer in a multilayer deposit, BSA 1 (Uniform Deposit) is continued. If $Z_{\text {fut }}$ is equal to or greater than the allowable scour depth, $Z_{\text {thresh, }}$ BSA 2 should be undertaken. Otherwise, the bridge is deemed "minimal risk" and should undergo regular monitoring. However, if the bridge does experience a major flood, for example the 100-year flood, BSA 1 should be carried out again soon after to assess the bridge for a future flood after having undergone the major flood.

\section{HYDRAULIC AND HYDROLOGIC ANALYSIS FOR BSA 1}

The required hydraulic information for BSA 1 is $V_{\text {fut }} / V_{\text {mo. }}$. From this point forward, the term $\mathrm{V}_{100}$ will substitute the term $\mathrm{V}_{\text {fut }}$ when the future flood event is specifically considered as the 100-year flood. There are two cases pertaining to the availability of flow gages (flow data) when estimating $\mathrm{V}_{\text {fut }} / \mathrm{V}_{\text {mo }}$, i.e. when flow data is available or unavailable at the bridge.

Obtaining the velocity ratio when flow data is available at the bridge being assessed for scour

In this case, the hydraulic information required for BSA 1 can be determined in a fairly straightforward manner as follows:

1. Obtain the time series of annual instantaneous flow peaks at the bridge location.

2. Perform flood frequency analysis (FFA) on unregulated flow records to obtain the flow corresponding to the 100-year flood, $\mathrm{Q}_{100}$.

3. Determine the maximum flow value from the time series ignoring data recorded before the bridge was constructed. This flow value is the maximum flood experienced by the bridge $Q_{\text {mo }}$.

4. Convert $\mathrm{Q}_{100}$ and $\mathrm{Q}_{\mathrm{mo}}$ into $\mathrm{V}_{\text {fut }}$ and $\mathrm{V}_{\text {mo }}$, respectively using typical hydraulic analysis tools such as HEC-RAS. The software TAMU-FLOW, which models the relationship between the discharge and velocity in uniform flow, was developed for this study. TAMU-FLOW is simpler to use than HEC-RAS and is available from the authors at no cost.

5. Calculate $\mathrm{V}_{100} / \mathrm{V}_{\text {mo }}$.

\section{Obtaining the velocity ratio when flow data is unavailable at the bridge being assessed for scour}

In this case, $V_{\text {fut }} / V_{\text {mo }}$ should be inferred. This paper introduces a method which utilizes flow data collected at gages near the bridge being investigated. $V_{\text {fut }} / V_{\text {mo }}$ is determined as follows:

1. Obtain $\mathrm{Q}_{\mathrm{mo}}$ and it's corresponding recurrence interval $\mathrm{RI}_{\mathrm{Qmo}}$ at the nearby gages

2. Obtain $\mathrm{RI}_{\mathrm{Qmo}}$ at the bridge being assessed for scour by spatially interpolating $\mathrm{RI}_{\mathrm{Qmo}}$ observed at the nearby gages. This procedure is addressed in the proceeding section. 
3. Obtain $\mathrm{Q}_{100} / \mathrm{Q}_{\mathrm{mo}}$ using the relationship between $\mathrm{RI}_{\mathrm{Qmo}}$ and $\mathrm{Q}_{100} / \mathrm{Q}_{\mathrm{mo}}$ developed for this study (Figure 4). The development of the $\mathrm{RI}_{\mathrm{Qmo}}-\mathrm{Q}_{100} / \mathrm{Q}_{\mathrm{mo}}$ relationship is presented in a proceeding section.

4. Convert $\mathrm{Q}_{100} / \mathrm{Q}_{\mathrm{mo}}$ into $\mathrm{V}_{100} / \mathrm{V}_{\mathrm{mo}}$ using Manning's equation.

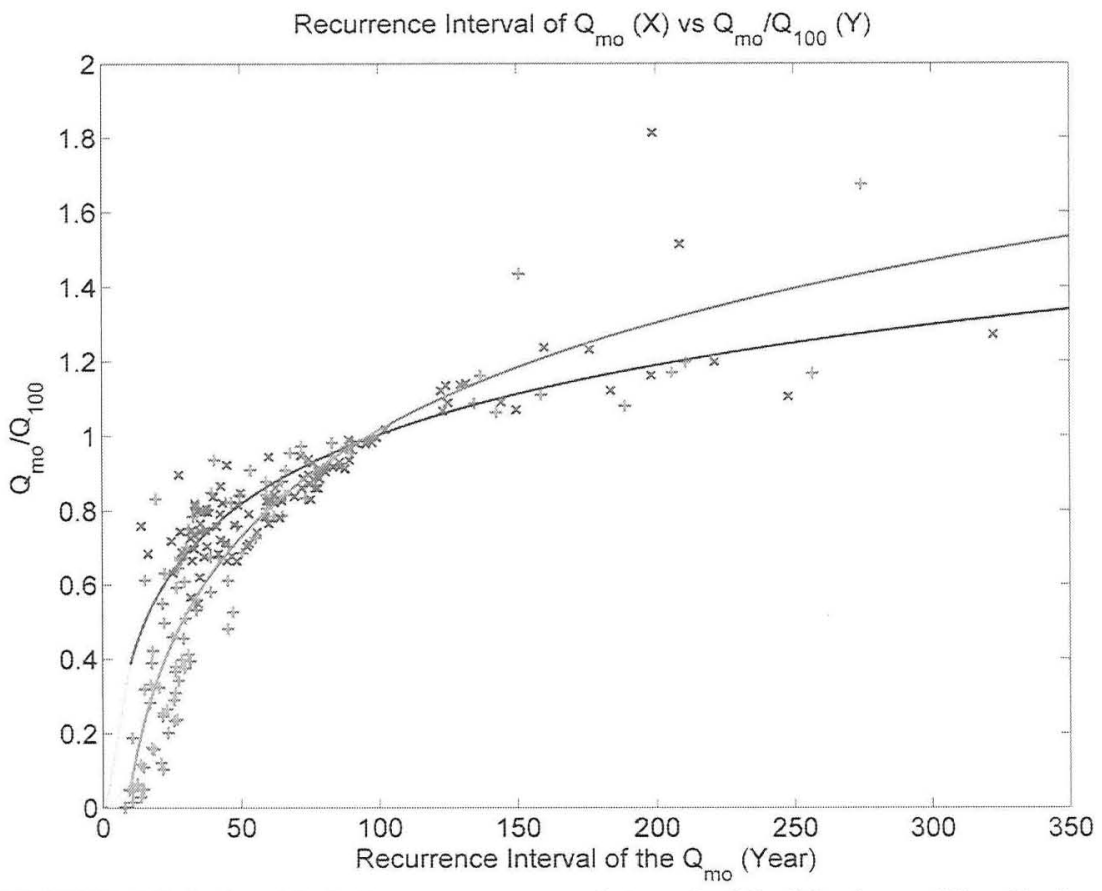

FIGURE 4 Relationship between recurrence interval of the Maximum Flow Peak and $\mathbf{Q}_{\mathrm{mo}} / \mathbf{Q}_{100}$.

Estimation of the recurrence interval of the maximum flow at bridge being assessed without flow data

The steps to determine the recurrence interval of $\mathrm{Q}_{\mathrm{mo}}$ at the bridge being assessed for scour is as follows:

1. Obtain the yearly flow peak data from flow gages that are close to the ungaged basin of concern, i.e. where the concerned bridge without flow data is located.

2. Perform FFA for all those gages to obtain the recurrence interval of the yearly instantaneous peak flow (YIPF) at all gage locations during the years of concern (i.e., starting from the year in which the bridge was built to the year of the most recent bridge inspection). 
3. For each year, spatially interpolate the recurrence interval of YIPF for the nearby gages to obtain the recurrence interval at the bridge being assessed for scour. Here, a linear interpolation method is used.

4. Obtain $\mathrm{RI}_{\mathrm{Qmo}}$ at the bridge being investigated during the period of concern by choosing the highest recurrence interval calculated in the preceding step during the specified period.

This procedure has been automated for the State of Texas in the software tool TAMU-FLOOD which was developed specifically for this study. TAMU-FLOOD is available from the authors at no cost. A snapshot of the software output is provided in Figure 5. Figure 5(a) shows the recurrence interval values of the flow peaks observed at flow gages for a given year while the inset shows the corresponding color shading resulting from the interpolation between gages. Figure $5(b)$ shows the color shaded recurrence interval between a specified time period, in this case between 1970 and 2006. This represents a scour assessment carried out in 2006 at a bridge that was built in 1970 .

Relationship between the Recurrence Interval of the Maximum Flow Peak RIQmo and $Q_{m o} / Q_{100}$

The $\mathrm{RI}_{\mathrm{Qmo}}-\mathrm{Q}_{\mathrm{mo}} / \mathrm{Q}_{100}$ relationship shown in Figure 4 is based on data from 101 USGS flow gages across Texas. The reader is referred to Briaud et al. (2009) for details of these gages. For each gage, FFA was performed to obtain the recurrence interval of the maximum yearly peak discharge and also $\mathrm{Q}_{100}$. In Figure $4, \mathrm{Q}_{\mathrm{mo}} / \mathrm{Q}_{100}$ is plotted against the recurrence interval of the maximum observed flow at each station. The scatter of cross $(\mathrm{x})$ signs results from FFA that was carried out using the generalized extreme value distribution and L-moments method (GEV-LMOM). The scatter of plus signs (+) results from FFA using the generalized extreme value distribution and maximum likelihood method (GEV-MLE). Detailed descriptions on GEV-LMOM and GEV-MLE are given in Hosking and Wallis (1997). 


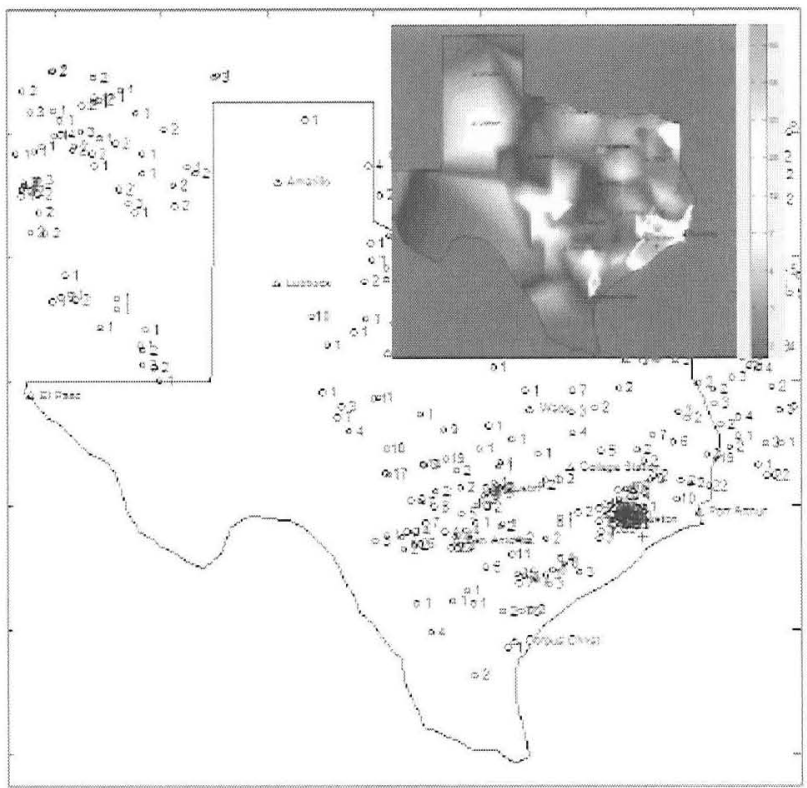

(a)

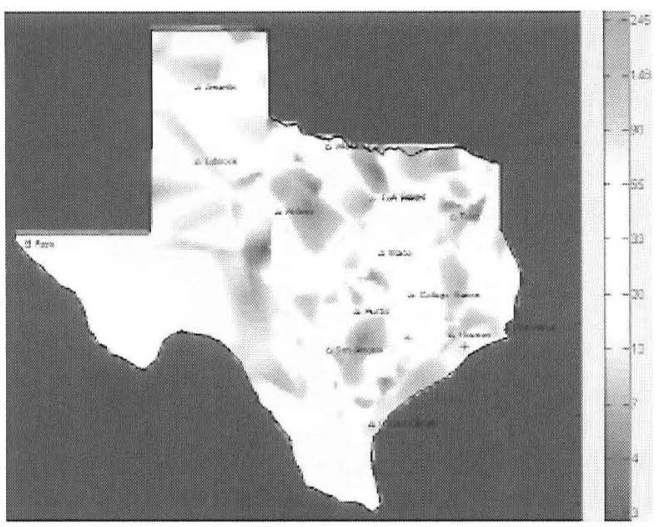

(10)

FIGURE 5 TAMU-FLOOD Output. 
In Figure 4, the relationship between the two variables is apparent with $\mathrm{R}^{2}$ of 0.71 (GEV-LMOM) and 0.83 (GEV-MLE). Thus, this study suggests the following regression equations to obtain the ratio $\mathrm{Q}_{\mathrm{mo}} / \mathrm{Q}_{100}$ from the recurrence interval estimated from the maximum flow peak:

When GEV-LMOM is preferred:

$$
\begin{gathered}
\frac{\mathrm{Q}_{\mathrm{mo}}}{\mathrm{Q}_{100}}=0.4141 \ln \left(\mathrm{RI}_{\mathrm{Qmo}}\right)-0.89 \text {, if } \mathrm{RI}_{\mathrm{Qmo}}>10 \\
\frac{\mathrm{Q}_{\mathrm{mo}}}{\mathrm{Q}_{100}}=\frac{0.0635}{9}\left(\mathrm{RI}_{\mathrm{Qmo}}-1\right), \text { if } \mathrm{RI}_{\mathrm{Qmo}} \leq 10
\end{gathered}
$$

When GEV-MLE is preferred:

$$
\begin{aligned}
& \frac{\mathrm{Q}_{\mathrm{mo}}}{\mathrm{Q}_{100}}=0.2682 \ln \left(\mathrm{RI}_{\mathrm{Qmo}}\right)-0.2315, \text { if } \mathrm{RI}_{\mathrm{Qmo}_{\mathrm{mo}}}>10 \\
& \frac{\mathrm{Q}_{\mathrm{mo}}}{\mathrm{Q}_{100}}=\frac{0.3861}{9}\left(\mathrm{RI}_{\mathrm{Qmo}}-1\right), \text { if } \mathrm{RI}_{\mathrm{Qmo}} \leq 10
\end{aligned}
$$

In Equations (2) through (5), $\mathrm{RI}_{\mathrm{Qmo}}$ is the recurrence interval of YIPF. Equations (2) and (4) can yield negative values of $\mathrm{Q}_{\mathrm{mo}} / \mathrm{Q}_{100}$ for small recurrence intervals (i.e., less than 2 years). To prevent this, the portion of the equation that yields the negative recurrence interval was linearly interpolated and presented as Equations (3) and (5).

$\mathrm{Q}_{\mathrm{mo}} / \mathrm{Q}_{100}$ is then converted into $\mathrm{V}_{100} / \mathrm{V}_{\text {mo }}$ using Manning's equation. This can be done without knowing explicit values of $V_{m o}$ and $V_{100}$. The relationship between $\mathrm{Q}_{\mathrm{mo}} / \mathrm{Q}_{100}$ and $\mathrm{V}_{100} / \mathrm{V}_{\mathrm{mo}}$ using Manning's equation is as follows:

$$
\left[\frac{\mathrm{Q}_{1}}{\mathrm{Q}_{2}}\right]^{\frac{1}{4}}<\frac{\mathrm{V}_{1}}{\mathrm{~V}_{2}}<\left[\frac{\mathrm{Q}_{1}}{\mathrm{Q}_{2}}\right]^{\frac{2}{5}}
$$

The derivation of Equation (6) can be found in Briaud et al. (2009). The choice of the exponent $(0.25-0.4)$ can be made based on the shape of the channel cross section. If the flow depth is small compared to the width, an exponent that is close to 0.4 can be used. If the flow depth is large compared to the width, an exponent close to 0.25 can be adopted. Most rivers fall in the category of wide and shallow, and an exponent of 0.35 may be a reasonable approximation on average.

\section{Validation of method to obtain flow parameters}

To investigate if the estimated ratio $\mathrm{V}_{\mathrm{mo}} / \mathrm{V}_{100}$ is close to the observed ratio $\mathrm{V}_{\mathrm{mo}} / \mathrm{V}_{100}$, an approach called cross-validation was used and is as follows:

1. Obtain the recurrence interval of an observed flood at a gage. 
2. Assume the flow gage is nonexistent and estimate the recurrence interval at the gage by spatially interpolating observed data from nearby gages. This value is the cross-validated recurrence interval (CVRI).

3. Calculate $\mathrm{Q}_{\mathrm{mo}} / \mathrm{Q}_{100}$ for both the observed and cross-validated recurrence intervals using Equations (2) through (5).

4. Convert $\mathrm{Q}_{\mathrm{mo}} / \mathrm{Q}_{100}$ into $\mathrm{V}_{\mathrm{mo}} / \mathrm{V}_{100}$.

5. Compare $\mathrm{V}_{\mathrm{mo}} / \mathrm{V}_{100}$ from the observed recurrence interval and CVRI.

A match between the observed and cross-validated values would indicate spatial tendency. The cross validation of $\mathrm{V}_{\mathrm{mo}} / \mathrm{V}_{100}$ was performed for all observed flow peaks in Texas between 1950 to 2006, involving 27,070 flow peaks. Among these, the ones observed at gages that were within 120 miles from other gages were chosen for further analysis (a total of 3845 flow peaks). This filtering criterion was used because even the largest storm observed at one location in a given year has a limited spatial coverage, which was assumed to be 120 miles in this study. The result of the cross validation is shown in Figure 6(a). The correlation coefficient between the two variables is 0.61 indicating that $\mathrm{V}_{\mathrm{mo}} / \mathrm{V}_{100}$ at the bridge location without a flow gage can be predicted, with a certain degree of accuracy from a hydrologic sense by spatially interpolating the results from the gages within this distance. The slope and the intercept of the regression equation was 0.58 and 0.2 , respectively. The 1:1 line and the regression equation meet when $\mathrm{V}_{\mathrm{mo}} / \mathrm{V}_{100}$ equals 0.45 . This suggests that the predicted $\mathrm{V}_{\mathrm{mo}} / \mathrm{V}_{100}$ greater than 0.45 is generally under-estimated, and vice versa.

Figure 6(b) shows the histogram of the error between the cross-validated and observed velocity ratio. The histogram was produced to quantify the level of error inherent in the suggested approach. The discrepancy between the two variables is distributed in a bell shape with mean, $\mu=-0.04$ and standard deviation, $\sigma=0.18$. Assuming that the error is normally distributed, the predicted $\mathrm{V}_{\mathrm{fu}} / \mathrm{V}_{\mathrm{mo}}$ using the suggested approach would be such that:

$$
\begin{gathered}
\mathrm{P}\left[\mu-\sigma<\frac{\mathrm{V}_{\mathrm{mo}}}{\mathrm{V}_{100}(\mathrm{obs})}-\frac{\mathrm{V}_{\mathrm{mo}}}{\mathrm{V}_{100(\mathrm{CV})}}<\mu+\sigma\right]=\mathrm{P}\left[-0.22<\frac{\mathrm{V}_{\mathrm{mo}}}{\mathrm{V}_{100}(\mathrm{obs})}-\frac{\mathrm{V}_{\mathrm{mo}}}{\mathrm{V}_{100(\mathrm{CV})}}<0.16\right]=0.68 \\
\mathrm{P}\left[\mu-2 \sigma<\frac{\mathrm{V}_{\mathrm{mo}}}{\mathrm{V}_{100}(\text { (obs) }}-\frac{\mathrm{V}_{\mathrm{mo}}}{\mathrm{V}_{100}(\mathrm{CV})}<\mu+2 \sigma\right]=\mathrm{P}\left[-0.40<\frac{\mathrm{V}_{\mathrm{mo}}}{\mathrm{V}_{100}(\mathrm{obs})}-\frac{\mathrm{V}_{\mathrm{mo}}}{\mathrm{V}_{100(\mathrm{CV})}}<0.32\right]=0.95
\end{gathered}
$$

The uncertainty analysis of the suggested approach presented in Figure 6 would help the user in employing engineering judgment when using the method. For example, Figure 6 and Equation 7 suggest that if the calculated $\left(\mathrm{V}_{\mathrm{mo}} / \mathrm{V}_{100}\right)$ is 0.5 , the actual $\left(\mathrm{V}_{\mathrm{mo}} / \mathrm{V}_{100}\right)$ can range from $0.28(=0.5-0.18-0.04)$ to $0.64(=0.5+0.18-0.04)$ with $\sim 70 \%$ confidence. 


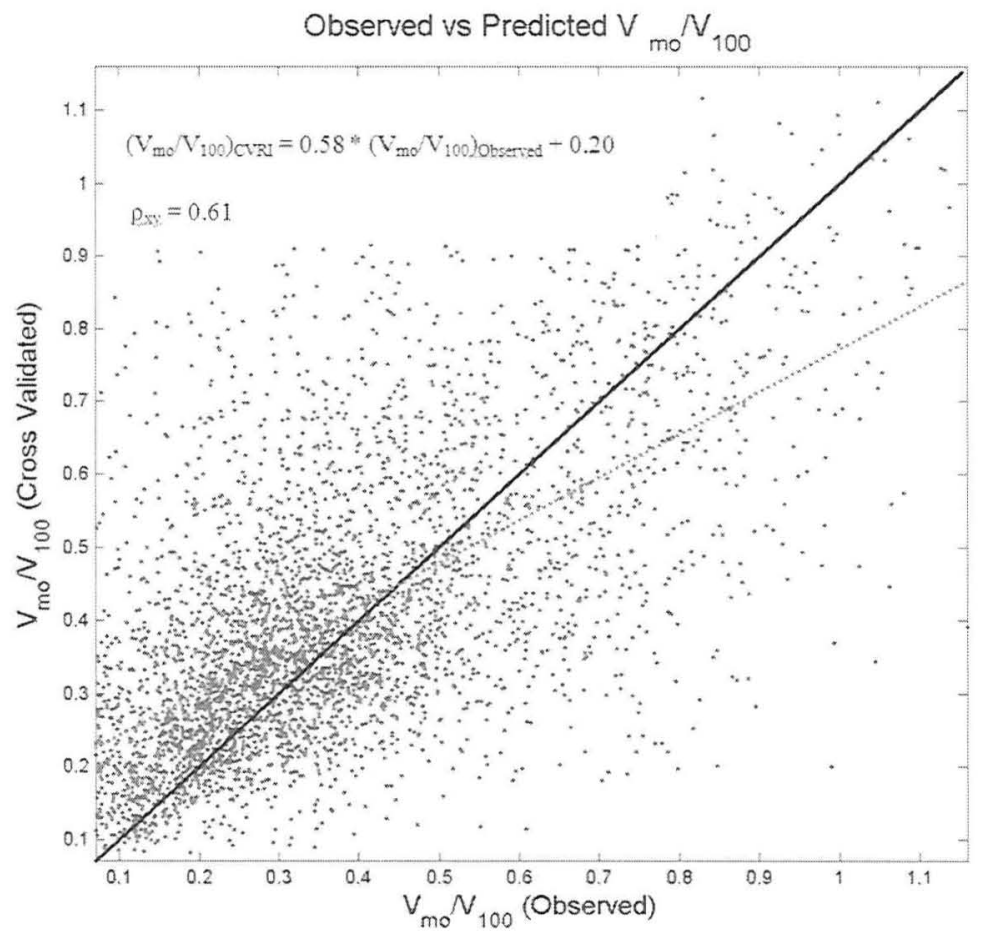

(a)

Histogram of the error between the cross-validated $V_{\text {mo }} V_{100}$ and the observed $V_{\text {mo }} V_{100}$

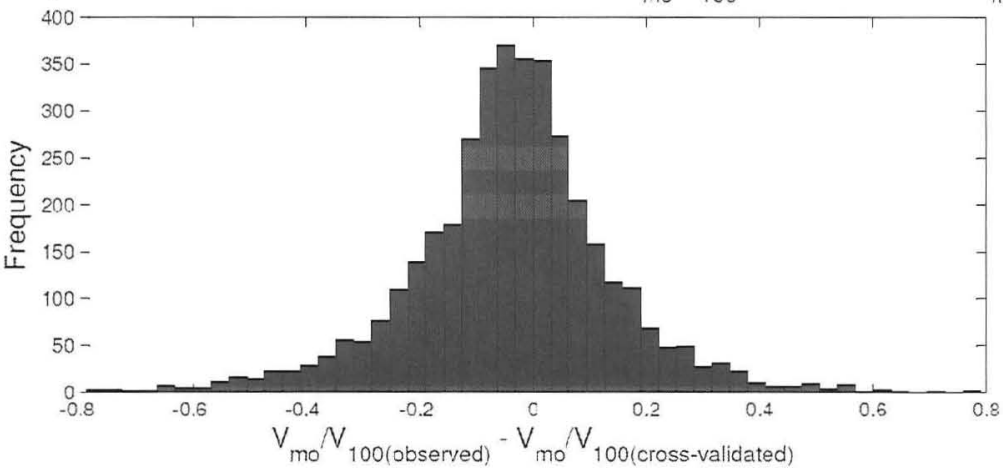

(b)

FIGURE 6 Relationship between Observed versus Cross-Validated $V_{\text {mo }} / V_{100}$. 


\section{VALIDATION OF BSA 1}

The validation of BSA 1 is aimed at evaluating how well results of BSA 1 match actual field measurements. This is performed by using both flow records and scour measurements at a particular case history bridge. The underlying concept behind the validation procedure is to go back in time and perform a BSA 1 analysis at the bridge and predict a future scour depth value $Z_{\text {fut }}$ for a specified time in the future that coincides with when an actual measurement was taken. The validation is simply a comparison between $Z_{\text {fut }}$ obtained through BSA 1 at that moment back in time and the actual measurement. In this investigation, nine bridge case histories in Texas were selected for validation. Bridge inspection folders for them were obtained from TxDOT. These were bridges with flow records. In order to carry out a meaningful validation, actual flow records recorded by a suitable flow gage were used. The validation process is summarized as follows:

1. The validation procedure starts at the time the first scour measurement was taken at a particular case history bridge. This time is called $T_{1}$ and could represent a particular date, e.g., August 21, 1952, or even a year, say 1952.

2. From the measured velocity time history, the maximum flow velocity experienced by the bridge until $\mathrm{T}_{1}$, termed $\mathrm{V}_{\text {mol }}$, is obtained. The scour depth measured at the bridge, $Z_{\text {mol }}$, at time $T_{1}$ is obtained from bridge inspection records.

3. A "mock" scour prediction is made at $T_{1}$ for a future flood event with velocity $\mathrm{V}_{\text {fut } 1}$ over the next scour measurement interval time, $\mathrm{t}_{\text {measl }}$. It is required that there be actual scour measurements taken at the bridge site at time $T_{1}+t_{\text {measl }}$. $V_{\text {fut } 1}$ is the maximum velocity obtained between $T_{1}$ and $T_{1}+t_{\text {meas }}$.

4. The Z-Future Chart is then used to obtain the scour depth ratio $Z_{\text {fut }} / Z_{\text {mo }}$ by using the velocity ratio $V_{\text {fut }} / V_{\text {mo. }}$. In this case, $Z_{m o}$ is $Z_{\text {mol }}, V_{\text {fut }}$ is $V_{\text {fut } 1 \text {, and }} V_{\text {mo }}$

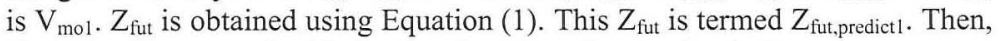
$Z_{\text {fut,predict } 1}$ is compared with the actual measured scour depth, $Z_{\text {fut,meas } 1}$.

5. Steps 1 through 4 are repeated for the remaining bridge inspection records.

The validation process might yield one or more sets of predicted and measured scour depth for each of the selected bridge case histories. The bridge records had limited bridge scour measurements. In fact, there were no bridge scour measurements taken before the year 1991. Since most of the bridges were reasonably old, they had experienced the largest flow velocity prior to the first bridge scour measurement. This resulted in all the cases having a $V_{\text {fut }} / V_{\text {mo }}$ ratio of equal to or less than unity. Results of the validation are shown in Figure 7 where they are plotted against the equal value line. There appears to be good agreement between predicted and measured values. 


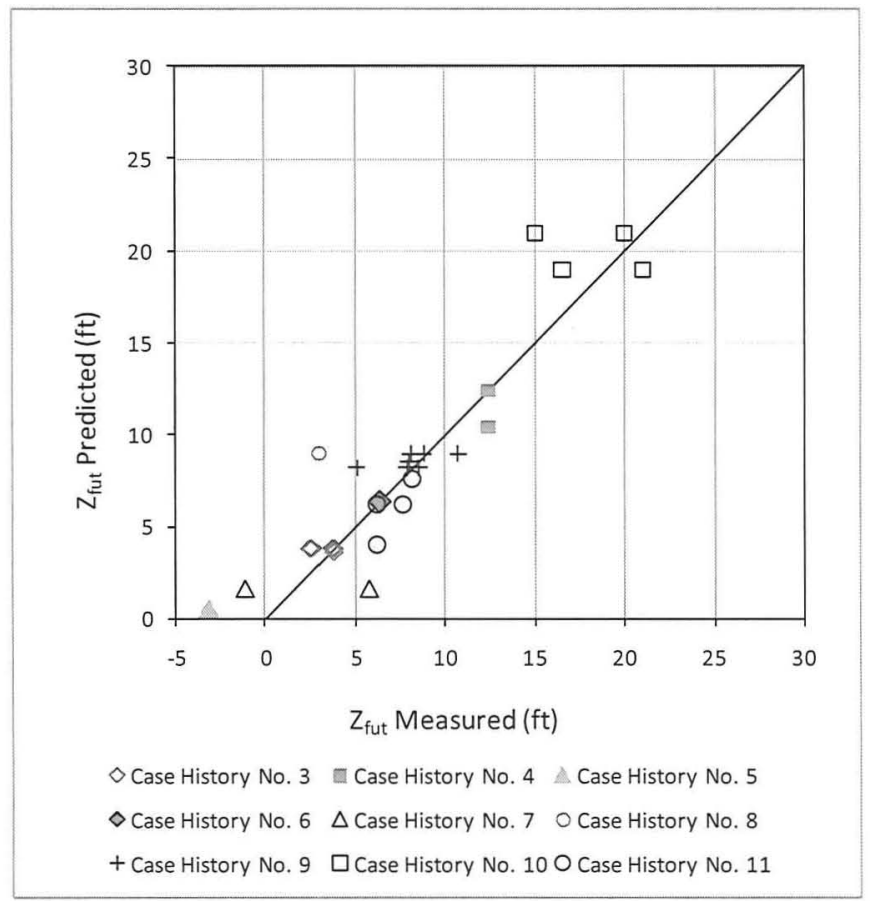

FIGURE 7 BSA 1 validation results.

\section{EXAMPLE APPLICATION OF THE PROPOSED METHOD}

Problem: Determine the future scour depth corresponding to the 100 -year flood for the following information that characterizes the bridge scour problem:

- Geomaterial type is uniform medium erodibility material (Category III).

- Contraction ratio $\mathrm{R}_{\mathrm{c}}=\mathrm{B}_{2} / \mathrm{B}_{1}=0.85$, upstream water depth $\mathrm{H}_{1}=32.8 \mathrm{ft}(10 \mathrm{~m})$, and pier diameter $\mathrm{D}=3.28 \mathrm{ft}(1.0 \mathrm{~m})$.

- The age of the bridge $t_{\text {hyd }}=25$ years.

- The bridge is not founded in rock.

- The scour conditions are mostly clear-water scour, and a $0.98 \mathrm{ft}(0.3 \mathrm{~m})$ infilling is estimated to occur after big floods.

- The maximum observed scour depth $Z_{\mathrm{mo}}=6.56 \mathrm{ft}(2 \mathrm{~m})$.

- The allowable scour depth $Z_{\text {thresh }}=26.3 \mathrm{ft}(8 \mathrm{~m})$.

- The bridge was built in 1981 and assessed in 2006 .

- The longitude and latitude of the bridge are -96.0 and 30.0 , respectively.

The following is the solution according to BSA 1 flowchart box numbers (Figure 1):

- Box 1-1: Start of BSA 1 (Uniform Deposit). Proceed to Box 1-2.

- Box 1-2: The bridge is not founded in rock. Proceed to Box 1-5. 
- Box 1-5: $Z_{\mathrm{mo}}=2 \mathrm{~m} ; \mathrm{Z}_{\text {thresh }}=8 \mathrm{~m}$. Proceed to Box 1-6.

- Box 1-6: Infilling is important. Proceed to Box 1-7.

- Box 1-7: Infilling can be quantified.

- Box 1-10: Infilling is estimated at $0.3 \mathrm{~m}$. Proceed to Box 1-11.

- Box 1-11: $Z_{\mathrm{mo}}=2+0.3=2.3 \mathrm{~m}$. Proceed to Box 1-12.

- Box 1-12: $Z_{\mathrm{mo}}<Z_{\text {thresh. }}$ Proceed to Box 1-14.

- Box 1-14: To get the velocity ratio $\mathrm{V}_{\text {fut }} / \mathrm{V}_{\mathrm{mo}}=\mathrm{V}_{100} / \mathrm{V}_{\mathrm{mo}}$, launch the computer program TAMU-FLOOD and input the following parameters (Figure 8):

- Input the longitude and latitude of the bridge (-96.0 and 30.0, respectively).

- Input the year the bridge was built (1981) and the year of the BSA 1 assessment (2006).

- Choose the Log-Pearson Type III-MOM flood frequency analysis method.

- Run TAMU-FLOOD. The lower portion of Figure 8 shows the TAMUFLOOD output, where the maximum recurrence interval of flow at the bridge is 17 years and $\mathrm{V}_{\mathrm{mo}} / \mathrm{V}_{100}$ is between 0.6 and 0.8 . Taking $\mathrm{V}_{\mathrm{mo}} / \mathrm{V}_{100}$ as $0.7, \mathrm{~V}_{100} / \mathrm{V}_{\mathrm{mo}}=1.4$.

- Box 1-15: Medium erodibility material (Category III). Proceed to Box 1-16.

- Box 1-16: From Figure 3(b), $Z_{\text {fut }} / Z_{\text {mo }}=1.5$ for a 25 -year-old bridge. In this case, $Z_{\text {fut }}=Z_{100}$

$$
\begin{aligned}
Z_{\text {fut }}=Z_{100} & =1.5 \times Z_{\mathrm{mo}} \\
& =1.5(7.54 \mathrm{ft})=1.5(2.3 \mathrm{~m}) \\
& =11.3 \mathrm{ft}(3.5 \mathrm{~m})
\end{aligned}
$$

Proceed to Box 1-17.

- Box 1-17: The bridge is founded on a uniform soil deposit.

- Box 1-19: $Z_{\text {fut }}=Z_{100}=3.5 \mathrm{~m}=11.5 \mathrm{ft} ; Z_{\text {thresh }}=8 \mathrm{~m}=26.2 \mathrm{ft}$. $Z_{\text {fut }}$ is less than $Z_{\text {thresh. Proceed to Box 1-21. }}$

- Box 1-21: The bridge is deemed "minimal risk" and should undergo regular monitoring. Although the bridge only experienced a 17 -year flood event, the results of the analysis predict that it is stable for the predicted 100-year event superimposed on top of the previous flood events. However, if the bridge does experience another major flood, BSA 1 should be carried out again soon after to assess the bridge for a future flood after having undergone the major flood.

It is to be noted here that the software tools TAMU-FLOOD and TAMU-FLOW as well as the Texas Department of Transportation report that describes BSA 1 in detail (Briaud et al. 2009) is available for free download at https://ceprofs.civil.tamu.edu/briaud/simplescour.htm. 


\section{THWU-Flood 1.00}

Help

- Imput Panel

Select the unit of coordinate

Decimals (i.e. -97.3456$)$

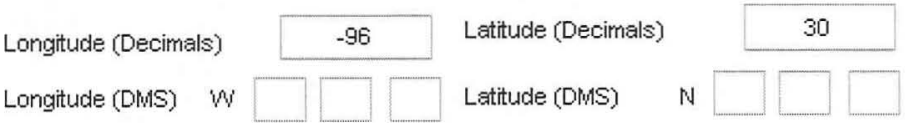

Year Bridge Built $1981 \quad \checkmark \quad$ Year Last Inspected 2006

Flood Frequency Analysis Wethods

Choose a method Log - Pearson Type III - MOM (USGS Custom)

- Output Format

I want flow map for each year - using only unregulated gages

I want flow map for each year - using all available gages

I want rainfall map for each year

6 hours

Generate Maps

- Outpurt

Maximum Rl of the bridge(Year) 17

$0.6<$ Vmon $100<0.8$

FIGURE 8 TAMU-FLOOD Input and Output for BSA 1 Example. 
TABLE 1 Results of the Application of BSA 1 to 16 Bridges in Texas

\begin{tabular}{|c|c|c|c|c|c|c|c|c|c|c|}
\hline 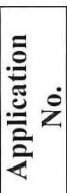 & 产 & $\sum^{20}$ & ఏ气 & $\underbrace{E}_{\text {E }}$ & 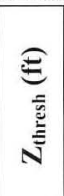 & 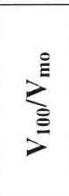 & 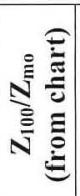 & $\begin{array}{l}\underbrace{\Xi}_{\Xi} \\
\text { N }\end{array}$ & 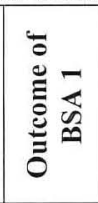 & 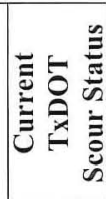 \\
\hline 1 & Sanders Creek & FM39 & Bent 5 & 1.5 & 11.3 & 1.05 & 1.10 & 1.7 & Stable & Critical \\
\hline 2 & Alligator Creek & US287 & Bent 3 & 13.1 & 16 & 1.04 & 1.20 & 15.7 & Stable & Critical \\
\hline 3 & Big Creek & $\mathrm{SH} 36$ & Bent 5 & 3.8 & 11 & 1.00 & 1.00 & 3.8 & Stable & Critical \\
\hline 4 & $\begin{array}{c}\text { San Marcos } \\
\text { River }^{\S}\end{array}$ & FM2091 & Bent 5 & 12.4 & 16 & 0.95 & $\S$ & $\S$ & $\S$ & Critical \\
\hline 5 & Mill Creek & FM331 & Bent 4 & 0.8 & 1.5 & 1.33 & 1.50 & 1.2 & Stable & Critical \\
\hline 6 & $\begin{array}{c}\text { Guadalupe } \\
\text { River }\end{array}$ & US87 & $\begin{array}{c}\text { Bent } \\
27 \\
\end{array}$ & 6.3 & 8.5 & 1.11 & 1.20 & 7.6 & Stable & Critical \\
\hline 7 & $\begin{array}{l}\text { San Jacinto } \\
\text { River }\end{array}$ & US59SB & $\begin{array}{c}\text { Bent } \\
15\end{array}$ & 5.7 & 0 & 1.11 & 1.20 & 6.8 & Critical & Critical \\
\hline 8 & $\begin{array}{l}\text { Dry Branch } \\
\text { Creek }\end{array}$ & $\mathrm{SH} 27$ & Bent 4 & 9 & 7.4 & 1.11 & $\dagger$ & $\dagger$ & $\dagger$ & Critical \\
\hline \multirow[b]{2}{*}{9} & \multirow[b]{2}{*}{ Peach Creek } & \multirow{2}{*}{$\begin{array}{c}\text { US59@ } \\
\text { Creekwood } \\
\text { Dr. } \\
\end{array}$} & Bent 2 & 8.5 & 17.5 & \multirow[b]{2}{*}{1.20} & \multirow[b]{2}{*}{1.35} & 11.5 & \multirow{2}{*}{ Stable } & \multirow[b]{2}{*}{ Critical } \\
\hline & & & Bent 3 & 12.1 & 17.5 & & & 16.3 & & \\
\hline 10 & Brazos River & $\begin{array}{c}\begin{array}{c}\text { US90A } \\
\text { (WB) }\end{array} \\
\end{array}$ & Bent 3 & 21 & 39 & 1.67 & 2.15 & 45.1 & Critical & Critical \\
\hline 11 & Navasota River & $\mathrm{SH} 7$ & Bent 5 & 8.1 & 17.5 & 1.17 & 1.35 & 11.0 & Stable & Stable \\
\hline \multirow{2}{*}{12} & \multirow{2}{*}{$\begin{array}{l}\text { North Bosque } \\
\text { River }\end{array}$} & \multirow{2}{*}{ SH 22} & Bent 8 & 5 & 16 & \multirow{2}{*}{1.43} & \multirow{2}{*}{1.55} & 7.8 & \multirow{2}{*}{ Critical } & \multirow{2}{*}{ Critical } \\
\hline & & & Bent 9 & 8 & 12 & & & 12.4 & & \\
\hline \multirow{2}{*}{13} & \multirow{2}{*}{$\begin{array}{c}\text { San Marcos } \\
\text { River }\end{array}$} & \multirow{2}{*}{$\mathrm{SH} 80$} & Bent 8 & 7.5 & 12 & \multirow{2}{*}{0.95} & \multirow{2}{*}{1.00} & 7.5 & \multirow{2}{*}{ Stable } & \multirow{2}{*}{ Stable } \\
\hline & & & Bent 9 & 10 & 12.5 & & & 10 & & \\
\hline 14 & Sims Bayou & SH $35 \mathrm{NB}$ & Bent 4 & 4 & 20 & 1.11 & 1.20 & 4.8 & Stable & Stable \\
\hline 15 & Bedias Creek & US 75 & \begin{tabular}{|c|} 
Bent \\
26
\end{tabular} & 8 & 8 & 1.18 & 1.30 & 10.4 & Critical & Critical \\
\hline 16 & Bedias Creek $^{*}$ & SH 90 & $*$ & $*$ & $*$ & $*$ & $*$ & $*$ & $*$ & Stable \\
\hline
\end{tabular}

Notes:

$\$$ A large caisson was added in 1995 at the scour critical pier. It was not possible to extrapolate $Z_{\mathrm{mo}}$ that corresponds to a smaller pier size to obtain $Z_{\text {fut }}$ for a larger pier size.

${ }^{\dagger} Z_{\text {mo }}$ exceeds $Z_{\text {thresh. }}$ The $9 \mathrm{ft}$ of scour was obtained in 1996 . However, the channel backfilled by $6 \mathrm{ft}$ in 1998 and this did not change until 2006.

"Channel excavation was carried out and no corresponding date was indicated in the bridge folder. 


\section{APPLICATION OF BSA 1 TO SCOUR CRITICAL BRIDGES}

In this study, 16 bridges were selected for application of BSA 1. Of these bridges, 11 were the same ones selected for validation, and 5 were additional bridges selected solely for the application process. TxDOT characterized 12 of the 16 bridges as scour critical and the remaining 4 as stable. Both stable and scour critical bridges were selected to test the proposed bridge scour assessment method and to compare it against TxDOT's scour designation.

For all cases evaluated, the future flow was taken as the 100-year flood with a corresponding velocity, $\mathrm{V}_{100}$. Results of the application of BSA 1 to the 16 bridges are provided in Table 1. The observations of the application procedure are summarizes as follows:

- 6 scour critical bridges were found to be stable by BSA 1

- 3 bridges could not be evaluated using BSA 1 due to reasons explained in the footnotes of Table 1

- 7 bridges had outcomes similar to the TxDOT designation, out of which 3 were stable and 4 were scour critical

- 6 of the 10 bridges that were originally scour critical and had sufficient information were found to be stable after BSA 1 according to the stability criterion.

\section{CONCLUSIONS AND RECOMMENDATIONS}

A new bridge scour estimation method termed BSA 1 was proposed. This method was sponsored by TxDOT, finalized in April 2009 and six months later has already been used by TxDOT engineers to evaluate 350 scour critical bridges in the State of Texas. The method overcomes the qualitative nature of current bridge scour evaluations by introducing a formal quantitative framework of a Level 1 analysis. The proposed method is relatively simple, economical and incorporates the field scour behavior of the bridge by using in-situ measurements. It does not require site-specific erosion testing. This paper also introduces a relatively simple and economical method to estimate hydraulic parameters required for scour analysis. The method has been developed for the State of Texas but its framework could be applied to any region having sufficient flow gages. BSA 1 was validated against actual field measurements and the results showed good agreement between measured and predicted values.

BSA 1 was applied to 10 scour critical and 3 non scour critical bridges. As a result of this, 6 of the 10 scour critical bridges were found to be stable and the 3 non scour critical bridges were confirmed as non scour critical. The procedure could introduce huge savings to bridge owners throughout the United States, and quite possibly worldwide.

The following are the authors' recommendations:

- Studies should be carried out to quantify the amount of infilling that takes place in live-bed scour conditions. This could be in the form of scourmonitoring methods or sediment transport analysis. 
- The level of risk associated with employing BSA 1 should be studied and addressed. It would be meaningful to determine the probability of the $Z_{\text {fut }} / Z_{\text {mo }}$ ratios predicted using BSA 1 exceeding field values.

- The time-dependent abutment scour depth should be included in BSA 1 and BSA 3.

- The software tool TAMU-FLOOD should be developed for all the states in the country.

\section{GLOSSARY OF SYMBOLS}

- $Z_{\text {fut }}=$ scour depth corresponding to a specified future flood

- $Z_{\mathrm{mo}}=$ maximum observed scour at the bridge when BSA 1 is performed

- $Z_{\text {fut }} / Z_{\text {mo }}=$ future scour depth ratio

- $V_{\text {fut }}=$ velocity corresponding to the specified future flood

- $\mathrm{V}_{\mathrm{mo}}=$ maximum velocity observed at the bridge when BSA 1 is performed

- $\mathrm{V}_{\text {fut }} / \mathrm{V}_{\mathrm{mo}}=$ future velocity ratio

- $Z_{\text {thresh }}=$ allowable scour depth of the foundation

- $Z_{\text {infill }}=$ thickness of infill in the scour hole

- $\mathrm{H}_{1}=$ upstream water depth

- $\mathrm{B}_{1}=$ uncontracted channel width

- $\mathrm{B}_{2}=$ contracted channel width

- $\mathrm{R}_{\mathrm{c}}=$ contraction ratio $=\mathrm{B}_{2} / \mathrm{B}_{1}$

- $\mathrm{V}_{\mathrm{c}}=$ critical velocity of geomaterial

- $\mathrm{D}=$ pier diameter

- $t_{\text {hyd }}=$ age of the bridge when BSA 1 is performed

- $Z_{\text {max }}$ Ratio = ratio of maximum (equilibrium) future scour depth to $Z_{\text {mo. This }}$ is applicable only to Category I and II materials.

- $\mathrm{Q}_{100}=$ flow corresponding the 100-year flood

- $\mathrm{Q}_{\mathrm{mo}}=$ flow value of the maximum flood experienced by the bridge when BSA 1 is performed

- $\mathrm{RI}_{\mathrm{Qmo}}=$ recurrence interval of $\mathrm{Q}_{\mathrm{mo}}$

\section{ACKNOWLEDGEMENTS}

This paper is an outcome of a bridge scour project funded by the Texas Department of Transportation (Grant No. 0-5505). The authors are grateful for this support.

\section{REFERENCES}

1. Briaud, J.-L., Ting, F.C.K., Chen, H.-C., Gudavalli, R., Perugu, S. and Wei, G. (1999). "SRICOS: Prediction of Scour Rate in Cohesive Soils at Bridge Piers," Journal of Geotechnical and Geoenvironmental Engineering, Vol. 125, No. 4, pp. 237 246. 
2. Briaud, J.-L., Ting, F.C.K., Chen, H.-C., Cao, Y., Han, S.W. and Kwak, K.W. (2001a) "Erosion Function Apparatus for Scour Rate Predictions." Journal of Geotechnical and Geoenvironmental Engineering, Vol. 127, No.2, pp. 105-113.

3. Briaud, J.-L., Chen, H.-C., Kwak, K.W., Han, S.W. and Ting, F.C.K. (2001b). "Multiflood and Multilayer Method for Scour Rate Prediction at Bridge Piers," Journal of Geotechnical and Geoenvironmental Engineering, Vol. 127, No. 2, pp. 114125.

4. Briaud, J.-L., Chen, H.-C., Li, Y., Nurtjahyo, P. and Wang, J. (2005). "SRICOSEFA Method for Contraction Scour in Cohesive Soils," Journal of Geotechnical and Geoenvironmental Engineering, Vol. 131, No. 10, pp. 1283-1294.

5. Briaud, J.-L. (2008). "Case Histories in Soil and Rock Erosion: Woodrow Wilson Bridge, Brazos River Meander, Normandy Cliffs, and New Orleans Levees - 2007 Ralph B. Peck Lecture," Journal of Geotechnical and Geoenvironmental Engineering, Vol. 134, No. 10, pp. 1425-1447.

6. Briaud J.-L., Govindasamy A.V., Kim, D., Gardoni, P., Olivera, F., Chen, H.-C., Mathewson, C., and Elsbury, K. (2009). "Simplified Method for Estimating Scour at Bridges," Report 0 5505-1, Texas Department of Transportation, Austin, Texas.

7. Cato, K.D. (1991). "Performance of Geologic Materials under Hydraulic Stress," Ph.D. Dissertation, Texas A\&M University, College Station, Texas

8. Govindasamy, A.V., Briaud, J.-L., Chen, H.-C., Delphia, J., Elsbury, K., Gardoni, P. Herrman, G., Kim, D., Mathewson, C.C., McClelland, M., and Olivera, F. (2008). "Simplified Method for Estimating Scour at Bridges," GeoCongress 2008, New Orleans, Louisiana, pp. 385-393.

9. Govindasamy, A.V. (2009). "Simplified Method for Estimating Future Scour Depth at Existing Bridges," Ph.D. Dissertation, Texas A\&M University, College Station, Texas.

10. Holnbeck, S.R. and Parrett, C. (1997). "Method for rapid estimation of scour at highway bridges based on limited site data," Water-Resources Investigations Report 96-4310, United States Geological Survey, Helena, Montana, pp. 79.

11. Hosking J.R.M and Wallis J.R. (1997). "Regional Frequency Analysis: An Approach based on L-Moments," Cambridge University Press, Cambridge, UK.

12. Huizinga, R.J. and Rydlund, P.H. (2004). "Potential-scour assessments and estimates of scour depth using different techniques at selected bridge sites in Missouri," Scientific Investigations Report 2004-5213, United States Geological Survey and Missouri Department of Transportation, Reston, Virginia, pp. 42. 
13. Johnson, P.A. (2005). "Preliminary Assessment and Rating of Stream Channel Stability Near Bridges," Journal of Hydraulic Engineering, Vol. 131, No. 10, pp. 845852.

14. Lagasse, P.F., Schall, J.D., Johnson, F., Richardson, E.V., and Chang, F. (1995). "Stream Stability at Highway Structures," Federal Highway Administration Report No. FHWA-IP-90-014 (HEC 20), Washington D.C., pp. 144.

15. Pagan-Ortiz, J. E. (1998). "Status of scour evaluation of bridges over waterways in the United States," Proc., ASCE Conf. on Water Resour. Engrg., ASCE, Reston, Va., pp. 2-4.

16. Richardson, E. V. and Davis, S.M. (2001). "Evaluating Scour at Bridges," Publication No. FHWA NHI 01-001 (HEC 18), United States Department of Transportation, Washington, D.C.

17. Simon, A., Outlaw, G.S., and Thoman, R. (1989). "Evaluation, modeling and mapping of potential bridge scour, West Tennessee," Proc., Bridge Scour Symp., Federal Highway Administration and United States Geological Survey, pp. 112-139.

18. Wang, J. (2004). "The SRICOS-EFA method for complex pier and contraction scour," Ph.D. Dissertation, Texas A\&M University, College Station, Texas. 